\title{
Estimation of peacock bass (Cichla spp.) mortality rate during catch-release fishing employing different post-capture procedures
}

\author{
L. S. A. Barroco ${ }^{a}$, C. E. C. Freitas ${ }^{a}$ and A. C. Lima ${ }^{a}$ \\ ${ }^{a}$ Department of Fisheries Sciences, Universidade Federal do Amazonas - UFAM, Mini Campus, \\ Av. General Rodrigo Otávio, 3000, Coroado I, CEP 69077-000, Manaus, AM, Brazil \\ *e-mail: cefreitas@ufam.edu.br
}

Received: October 31, 2015 - Accepted: November 16, 2016 - Distributed: May 31, 2018

(With 2 figures)

\begin{abstract}
The effect of catch-and-release fishing on the survival of peacock bass (Cichla spp.) was evaluated by comparing two types of artificial bait (jig and shallow-diver plugs) and two types of post-catch confinement. Two experiments were conducted during the periods January-February and October-November 2012 in the Unini River, a right-bank tributary of the Negro River. In total, 191 peacock bass were captured. Both groups of fish were subjected to experimental confinement (collective and individual) for three days. Additionally, 11 fish were tagged with radio transmitters for telemetry monitoring. Mortality rate was estimated as the percentage of dead individuals for each type of bait and confinement. For peacock bass caught with jig baits, mortality was zero. The corresponding figure for shallow-diver bait was $1.66 \%$ for fish in collective containment, $18.18 \%$ for fish monitored by telemetry and $0 \%$ for individuals confined individually. Our results show low post-release mortality rates for peacock bass. Furthermore, neither the type of confinement nor the type of bait had a statistically significant influence on mortality rates. While future studies could include other factors in the analysis, our results show that catch-and-release fishing results in low mortality rates.
\end{abstract}

Keywords: Cichla spp., angling, artificial baits, fish mortality, post-catch confinement.

\section{Estimativa da taxa de mortalidade do tucunaré (Cichla spp.) durante a prática do pesque-solte}

\section{Resumo}

O efeito do pesque-solte na sobrevivência do tucunaré (Cichla spp.) foi avaliado comparando dois tipos de iscas artificiais, jig e de meia-água, e dois tipos de confinamento pós-captura. Dois experimentos foram conduzidos durante os períodos de janeiro-fevereiro e outubro-novembro de 2012, no Rio Unini, afluente da margem direita do Rio Negro. No total, 191 tucunarés foram capturados. Os peixes foram submetidos a um confinamento experimental (coletivo e individual) com duração de três dias. Além disso, 11 peixes foram marcados com radiotransmissores e liberados imediatamente após a captura, sendo monitorados por telemetria. A taxa de mortalidade foi calculada como a porcentagem de indivíduos mortos para cada tipo de isca e tratamento (confinamento individual, coletivo e sem confinamento). Não houve mortalidade para o grupo de tucunarés capturados com isca jig. A isca de meia-água mostrou uma taxa de mortalidade de 1,66\% para o confinamento coletivo e 18,18\% para os peixes monitorados por telemetria. Nossos resultados mostraram baixas taxas de mortalidade pós-soltura para tucunaré. Além disso, nem o tipo de confinamento, nem o tipo de isca tiveram influência significativa nas taxas de mortalidade. Ainda que estudos futuros possam incluir novos fatores na análise, os nossos resultados mostram que a prática do pesque-solte resulta em baixas taxas de mortalidade.

Palavras-chave: Cichla spp., pesca, iscas artificiais, mortalidade de peixes, confinamento pós-captura.

\section{Introduction}

Sport fishing is an important activity worldwide (Cowx, 2002; Cooke and Suski, 2004). Its social importance and income-generating ability has been recognized in several countries (Pitcher and Hollingworth, 2002), including the United States of America (Muoneke and Childress, 1994; Siepker et al., 2007), Australia (Mcleay et al.,
2002; Broadhurst et al., 2005), several European countries (Aas et al., 2002; Veiga et al., 2011) and Brazil (Catella, 2004; Fabri, 2006; Holley et al., 2008; Sobreiro et al., 2010; Freire et al., 2012).

In Brazil, sport-fishing tourism has been growing since the beginning of the 90s (Holley et al., 2008). It is responsible, 
directly and indirectly, for approximately 200 thousands jobs, moving a total turnover of US\$ 500 million (Fabri, 2006). Anglers in various countries have identified Brazil as a special destination with a good pool of target species for sport fishing (PNDPA, 2006).

The rapid pace at which sport fisheries have developed in Amazonian blackwater rivers is closely related to the presence of large peacock bass (Cichla spp.) in these rivers. Three species of peacock bass can be found in the Negro River basin: Cichla orinocensis (Humboldt, 1821), Cichla temensis (Humboldt, 1821) and Cichla monoculus (Agassiz, 1831) (Kullander and Ferreira, 2006). The aggressive behavior of these species and the way that they attack the bait are the main characteristics that attract anglers from several parts of the world to the Amazonian region (Holley et al., 2008). The most important fishing grounds are located in the middle stretch of the Negro River and its tributaries the rivers Jurubaxi, Aracá, Demeni, Cuiuni, Caurés, Padauari, and Unini (Freitas and Rivas, 2006).

Sport fishing as regulated by the Brazilian Institute for the Environment and Renewable Natural Resources (IBAMA) is defined as recreational fishing in which the fish must be released after it has been caught and is known as catch-and-release fishing. This type of fishing is predominant in the middle stretch of the Negro River, particularly when peacock bass is the target species.

In the rivers of the Amazon Basin and Brazilian Pantanal, the efficiency of catch-and-release as a means of ensuring sustainable fish stocks remains the subject of debate. Some fishers, environmentalists, researchers and riverine people believe that released fish are highly vulnerable to predation by catfish, crocodilians and dolphins (Ceccarelli et al., 2005, 2006). There is some evidence that catch-and-release mortality rates are strongly influenced by the biological characteristics of the target species (Muoneke and Childress, 1994). However, certain other factors, such as the body part of the fish that was hooked (Pope et al., 2007; Alós et al., 2008), the type of bait (Reeves and Bruesewitz, 2007) and the fighting and handling time (Cooke and Suski, 2004) could also be determinants of mortality rate.

Broadhurst et al. (2005), studying the mortality rate of the main target species of Australian estuary sport fishing, reported mortality rates between 0 and $36.6 \%$ and found that the body part hooked and the time taken to release the fish were the main factors influencing mortality. Reeves and Bruesewitz (2007) estimated the mortality rate for catch-and-release of Sander vitreus to be between $0 \%$ and $12.2 \%$ and found that it was related to water temperature, bleeding intensity, fish size and the body part hooked. Alós et al. (2008) obtained similar values between 0\% and $17.9 \%$ and found that hook shape and size were the key factors. In a later study, Alós (2009) reported that the body part hooked was also a key factor.

Although peacock bass is the main target species for sport fishing in the Negro River basin (Holley et al., 2008), there are few published data on its post-release mortality rate. Thomé-Souza et al. (2014), in a study in which fish were confined for 72 hours post-catch, found mortality rates of between $2.3 \%$ and $5.2 \%$ for the three peacock bass species caught in the Negro River. However, their experimental design did not investigate the effects of bait type or post-catch confinement procedure, mainly related with the immediate release to address the question that the fish became vulnerable after capture. Aiming to fill this lacuna, the present study investigated the effects of both these factors on the mortality rate of peacock bass caught using two types of bait were in catch-and-release and including different post-catch confinement procedure at the experimental design.

\section{Material and Methods}

\subsection{Study area}

The study was carried out in the upper reach of the Unini River, a right-bank tributary of the middle Negro River (Figure 1). The Unini River was chosen because there are three environmental conservation units in its basin (Extractive Reserve Unini, Jaú National Park and Amanã Sustainable Development Reserve), where commercial fishing has been forbidden since 2008. There is no history of commercial fishing in the lakes in this region, which is close to the Village Vila Nunes consists of 5 small families, totaling 24 people (1 ${ }^{\circ} 37^{\prime} 35.87^{\prime \prime} \mathrm{S}$ and $\left.62^{\circ} 56^{\prime} 27.65^{\prime \prime} \mathrm{W}\right)$. People from the Village Vila Nunes, who are used to work as sport-fishing guides, were employed as guides and fishermen during this study.

\subsection{Data sampling}

Two field trips were done to perform the experiments, each lasting 35 days. The first was carried out in January and February 2012 and the second in October and November 2012. Fish were caught by seasoned fishers, including people who worked as fishing guides in the same area, using techniques and gear identical to those employed by recreational anglers. The experimental fishing was licensed by IBAMA (SISBIO 31951-1/authorization code 71137166) and was conducted in a motorized boat using a cooler filled with water from the river, where the fish caught were stored to reduce post-capture stress. Two types of bait were used: jigs (baits with just one single hook) and shallow-diver plugs (baits with two multiple hooks that run at mid-water) for studies with confinement, and only shallow-diver plugs for studies without confinement.

After the capture, we used three different procedures to monitor mortality rate for the different types of post-catch handling: (i) individual confinement of fish in small buoyancy cages, (ii) collective confinement in a surrounded area and (iii) tagging of fish with radio tags and immediate release after capture. The body part of fish wounded by the hook was visually identified.

To avoid excessive manipulation and stress for fish, they were keeping with a Boga Grip handless to measure total weight $(\mathrm{kg})$. At the same time, an automatic tape measure was employed to measure standard length $(\mathrm{cm})$ and fish girth $(\mathrm{cm})$. The time spent between catch and release into 


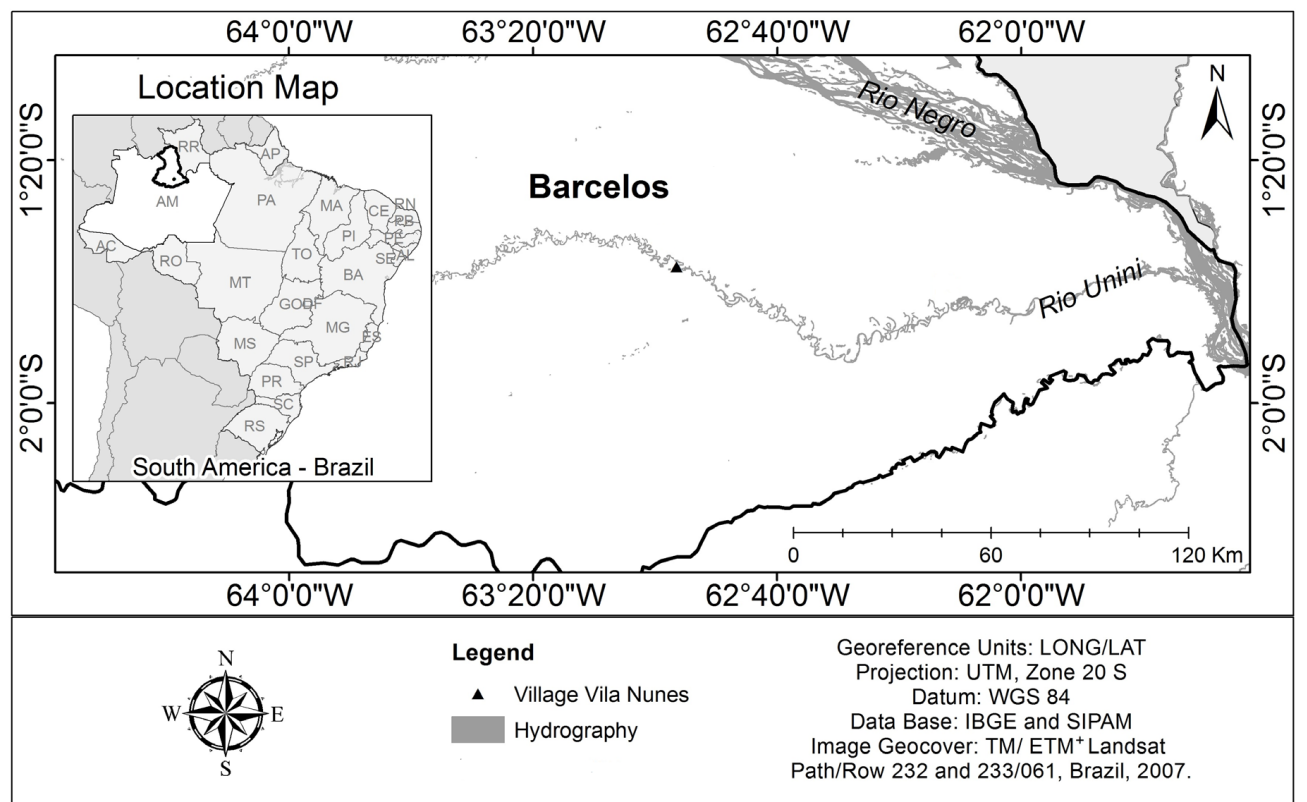

Figure 1. Location and hydrography of the middle Negro River showing the Unini River and Vila Nunes community, where the study was carried out.

the pen, cages or natural environment was also measured. All the experiments lasted three days, the time considered necessary to assess catch-and-release mortality, as deaths normally occur within the first twenty-fours following capture (Muoneke, 1992; Muoneke and Childress, 1994; Schill, 1996).

\subsubsection{Study using individual confinement}

Ten cages $1.5 \mathrm{~m}$ wide, $2.0 \mathrm{~m}$ long and $1.0 \mathrm{~m}$ high were used. These consisted of three different parts: (i) a rectangular surrounded area made of $10.0 \mathrm{~cm}$-diameter PVC tubes connected by elbow pieces and filled with $1.5 \mathrm{~L}$ PET (polyethylene terephthalate) soda bottles; (ii) a support for the net made of $2.5 \mathrm{~cm}$-diameter PVC pipes connected by $\mathrm{T}$ pieces at the four corners; and (iii) a black PVC 5 mm-mesh net sewn with nylon multifilament thread and fixed to the support structure (item ii) with $10 \mathrm{~cm}$-long PVC cable ties.

The cages were set up close to the banks of the main river channel, where the high flow rate ensured that the water in them was constantly renewed. To compare mortality rates for the two types of bait (jig baits and shallow-diver plugs), the procedure was carried out three times for each type of bait, giving a total of 60 peacock bass ( 10 fish $\times 3$ times x 2 types of bait).

\subsubsection{Study using collective confinement}

For this experiment, a $26.90 \mathrm{~m}$-long, $14.40 \mathrm{~m}$-wide, $1 \mathrm{~m}$-deep pen was used. This was made with a $100 \mathrm{~m}$-long, $2.5 \mathrm{~m}$-high net with a $3 \mathrm{~mm}$ mesh between opposite knots that was attached to the ground with 30 inch-long metal clasps. The net was supported with wooden sticks so that the sides stayed at least $1 \mathrm{~m}$ above the water surface. As in the other experiments, the mortality rates of peacock bass caught with jig baits or shallow-diver plugs were compared. The procedure was performed three times for each type of bait, with 20 fish confined in the surrounded area each time, giving a total of 120 fish $(20 \mathrm{fish} \times 3$ times $\times 2$ types of bait).

During the experiments, some fish jumped over the fence. These were considered survivors in our analysis because we considered the act of jumping over the fence a demonstration that the stress caused by catching and handling did not lead to physical exhaustion or affect the swimming performance of these fish.

\subsubsection{Telemetry study (no confinement)}

In this experiment, radio-acoustic transmitters with frequencies between 20 and $300 \mathrm{MHz}$ were used. These are the most suitable for research in fresh water (Reine, 2005). Active telemetry is the most commonly used technique in real-time monitoring. In this technique, the receiver is mounted in a small wooden boat, and the acoustic signals transmitted are used to track tagged fish (Holland et al., 1999). The strength of the received signal gives an idea of the distance between the boat and the fish and allows the fish to be monitored. The technique is an ideal method for answering questions related to short-term movements and the effects of stress or physical harm on the animal being monitored.

We used eleven model $\mathrm{F} 1835 \mathrm{~B}$ radio transmitters and two LA12-Q receivers. The transmitters were introduced into the stomach of the fish through the mouth. The reason for choosing this methodology was its less invasive nature and the fact that surgical procedures are not required.

Eleven peacock bass weighing more than $3 \mathrm{Kg}$ were tagged with a radio transmitter and released into their 
natural habitat. This experiment was conducted in lakes to facilitate location of the fish and avoid losing individuals fitted with transmitters. The eleven fish were then monitored for three days by active telemetry so that they could be located three times a day (morning, afternoon and night).

\subsection{Data analysis}

Mortality rate was calculated as the percentage of fish captured using a particular type of bait that died in each type of treatment. Data for weight, length and girth of the fish caught and time between capture and release were described by measures of central tendency (median e interquartile range - IQR). We used non-parametric procedures for the statistical analysis of the data because of the non-normal distribution (D'Agostino - Pearson normality test, at nominal level of significance of 0.05 ). The size of the fish caught with the two types of bait was compared with the Mann-Whitney U-test using weight, length and girth data. Also two Mann-Whitney U-test were employed to compare mortality rates by type of bait (jigs versus shallow-diver plugs) and confinement procedures (individual- versus collective confinement). We also plotted graphs to identify a possible relationship between the type of bait and the body part wounded. All analyses were performed using Statistica 9.0 (Statsoft Inc, 2009). The results of the statistical tests were interpreted with $\alpha=0.05$.

\section{Results}

\subsection{Study using individual confinement and fish caught with jig baits}

Thirty peacock bass were captured using jig baits. The fish had weights ranging from 0.5 to $3.5 \mathrm{Kg}$ (median $=0.5$, IQR $=0.5)$. Standard length varied from 22 to $55 \mathrm{~cm}$ (median $=35, \mathrm{IQR}=7$ ) and girth varied from 15 to $40 \mathrm{~cm}$ ( median $=24, \mathrm{IQR}=5)$. Transport times between capture and release in the cages ranged from 4 to 47 minutes ( median $=20, \mathrm{IQR}=16$ ). After three days of confinement in cages, none of the fishes had died.

\subsection{Study using individual confinement and fish caught with shallow-diver plugs}

Thirty peacock bass were caught using shallow-diver baits. The fish had weights ranging from 0.5 to $4 \mathrm{Kg}$ (median $=0.75, \mathrm{IQR}=1)$. Standard length varied from 26 to $59 \mathrm{~cm}($ median $=37.5, \mathrm{IQR}=9)$, and girth varied from 17.5 to $45 \mathrm{~cm}($ median $=27, \mathrm{IQR}=7)$. Transport times between capture and release into the cages ranged between 1 and 50 minutes $($ median $=15.5, \mathrm{IQR}=17$ ). As with the fish caught using jig baits, none of the fishes had died after three days of confinement in the cages.

\subsection{Study using collective confinement and fish caught with jig baits}

Sixty peacock bass were captured using jig baits. The fish had weights ranging from 0.5 to $7 \mathrm{Kg}$ (median $=1$, IQR = 1). Standard length varied from 18 to $68 \mathrm{~cm}$ (median
$=37, \mathrm{IQR}=12$ ), and girth varied from 16 to $52 \mathrm{~cm}$ ( median $=25$, IQR $=7$ ). Transport time between capture and release varied from 3 to 56 minutes (median $=24.5$, $\mathrm{IQR}=18$ ). After three days of confinement in the pen, the mortality rate was $0 \%$.

\subsection{Study using collective confinement and fish caught with shallow-diver plugs}

Sixty peacock bass were caught with shallow-diver plugs. The fish had weights ranging from 0.5 to $7.5 \mathrm{Kg}$ $($ median $=1, \mathrm{IQR}=2)$. Standard length varied from 24 to $68 \mathrm{~cm}($ median $=38, \mathrm{IQR}=15)$, and girth varied from 17 to $52 \mathrm{~cm}($ median $=28, \mathrm{IQR}=11)$. Transport time between capture and release varied from 4 minutes to 1 hour and 13 minutes $($ median $=26.5, \mathrm{IQR}=21)$. At the end of this experiment, only one fish had died, corresponding to a mortality rate of $1.66 \%$. The fish in question died during the third hour after release in the pen.

\subsection{Effects of housing on mortality rate}

There was no difference in mortality rate between fish in individual confinement and those in collective confinement (Mann-Whitney, $\mathrm{U}=15, \mathrm{p}=0.404$ ). Overall mortality rate for the 90 individuals caught with jig baits was therefore $0 \%$. The corresponding figure for the 90 individuals caught with shallow-diver plugs was $1.11 \%$. No intraspecific predation (cannibalism) was detected among the individuals in collective confinement. However, interspecific predation occurred when shallow-diver plugs were used as some of the confined peacock bass preyed upon Serrasalmus sp. that entered the pen.

\subsection{Effect of type of bait on mortality rate}

There was no difference in mortality rate between individuals caught with jig baits and those caught with shallow-diver plugs (Mann-Whitney, $U=15, p=0.404$ ), showing that the type of bait used had no effect on mortality. As we did not observe any effects for type of confinement, overall mortality rate calculated considering all 180 specimens of peacock bass, regardless of the type of bait used and the confinement to which they were subjected, was $0.55 \%$.

\subsection{Relation between type of bait and fish wounds}

Of the specimens of peacock bass caught with jig baits, $81.11 \%$ were hooked in the inner region of the mouth, and $7.39 \%$ of these had bleeding wounds. The gills were the only organs affected, with $18.89 \%$ of the fish being hooked in the gills, all with bleeding. The majority of the specimens caught with shallow-diver plugs were hooked in the inner region of the mouth $(57.43 \%)$; of these, $7.92 \%$ had bleeding wounds. Those hooked in the outer region of the mouth $(16.83 \%)$ had no bleeding wounds. Only $1.98 \%$ of the specimens hooked by the body (18.81\%) had injuries that were bleeding. All the specimens hooked in the gills $(5.94 \%)$ had bleeding injuries. An eye injury was observed in only one fish $(0.99 \%)$ and was not bleeding. 


\subsection{Size selectivity by type of bait}

Peacock bass caught with shallow-diver plugs had a tendency to be larger and have significantly larger weight, standard length and girth than those caught with jig baits (Figures 2a, 2b and 2c).

\subsection{Telemetry study (no confinement)}

Eleven peacock bass were caught with shallow-diver plugs. The fish had weights ranging from 3.5 to $7.5 \mathrm{Kg}$ $($ median $=5, \mathrm{IQR}=1)$. Standard length varied from 53 to $69 \mathrm{~cm}($ median $=61, \mathrm{IQR}=7)$, and girth varied from 40 to $52.5 \mathrm{~cm}$ (median $=45, \mathrm{IQR}=4.5$.

After three days of telemetry monitoring, only two fish died. One was an individual weighing $7.5 \mathrm{Kg}$ with a standard length of $69 \mathrm{~cm}$ and girth of $52.5 \mathrm{~cm}$, which was found dead approximately 2 hours after release (with no marks on its body to indicate predation). The other, which weighed $3.5 \mathrm{Kg}$ and had a standard length of $55 \mathrm{~cm}$ and girth of $45.5 \mathrm{~cm}$, was found dead on the afternoon of the second day of monitoring. Only one part of the body of this individual was found. The rest (from the base of the pectoral fin to the tail) may have been eaten by a predator. The mortality rate calculated at the end of this experiment was $18.18 \%$.
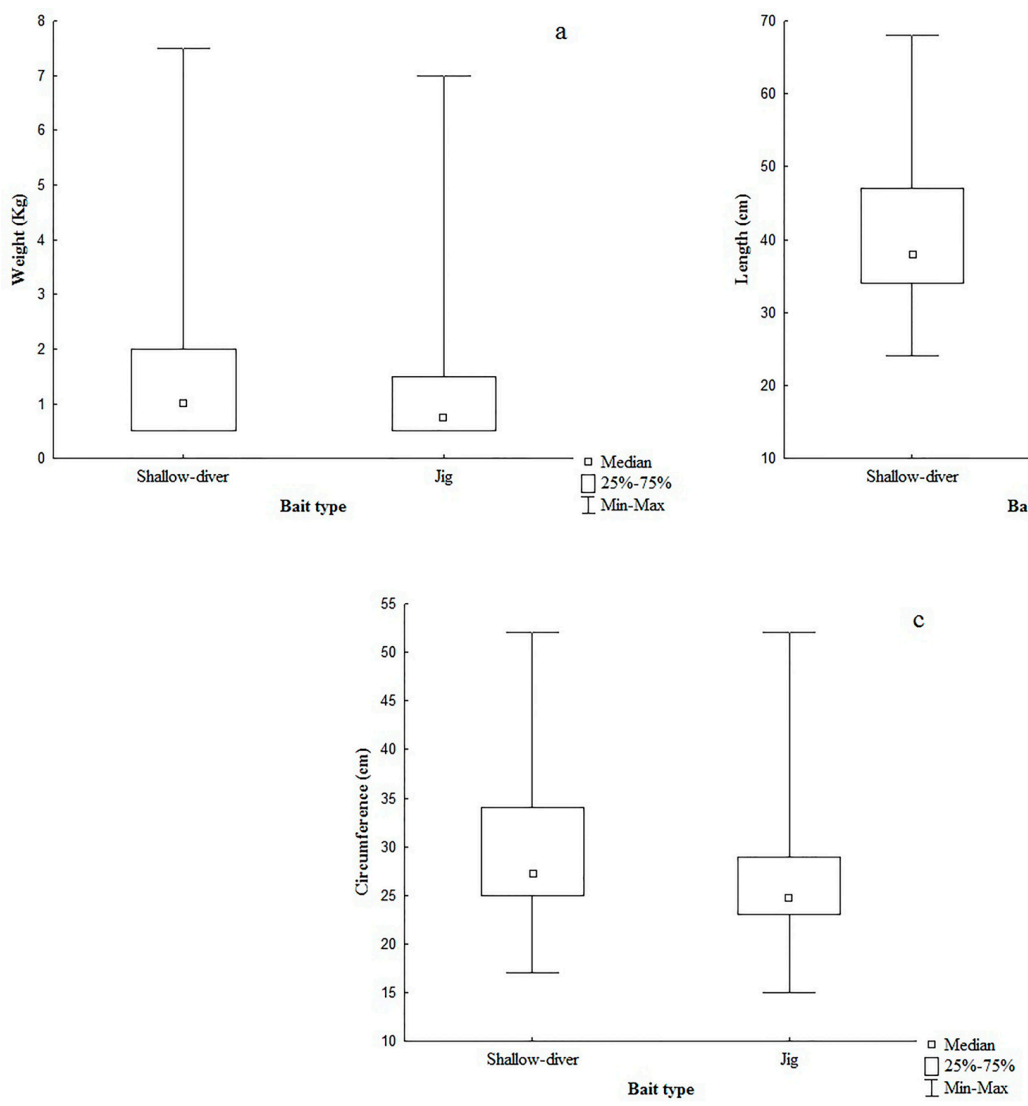

Figure 2. Box-plot based on the results of the Mann-Whitney test for comparison of the weight (a) $(U=1.99, p=0.04)$, length (b) $(\mathrm{U}=2.31, \mathrm{p}=0.02)$ and girth $(\mathrm{c})(\mathrm{U}=3.258, \mathrm{p}<0.01)$ of fish caught with shallow-diver plugs and jig baits showing the median, median \pm quartile and range.

\section{Discussion}

Considering the central objective to determinate the effects of bait type and post-catch confinement procedure on the peacock bass survivorship, we found very low mortality rates. When collective confinement was used, only one specimen of peacock bass died after release, while in individual confinement there was no mortality after three days of confinement. Mortality rates calculated for fish subjected to confinement should be considered conservative estimates (Pollock and Pine, 2007) because confinement does not simulate natural environmental conditions when the fish are returned to water (Alós, 2009). In contrast, the mortality rate in the experiment without confinement, in which telemetry was used to monitor the fish in their natural environment, was higher.

This difference may be directly related to the fact that when containment is used, fish caught using catch-and-release are protected from potentially greater vulnerability to predation whereas when released into the environment they will be available to other predators while they recover from the effects of catch-and-release (Cooke and Philipp, 2004; Thorstad et al., 2004). Cooke and Philipp (2004) found

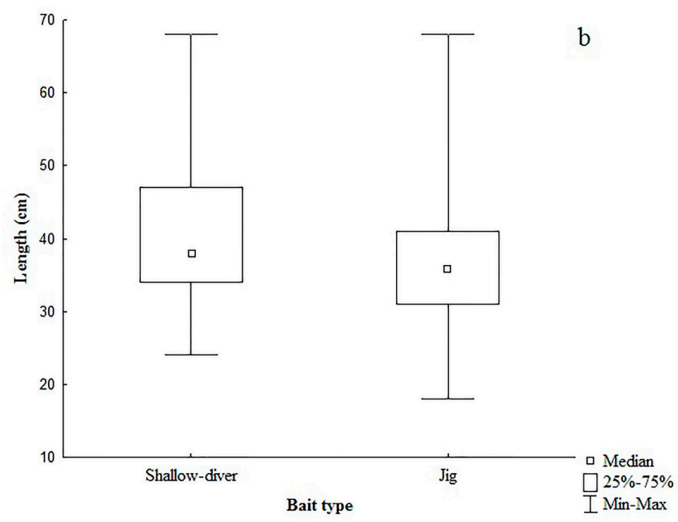


a mortality rate due to post-release predation of $39 \%$ for Albula spp. in a site with a high abundance of predators.

Our results partially corroborate a study of peacock bass mortality in the Negro River developed by Thomé-Souza et al. (2014). These authors found mortality rates between 2.3\% and $5.2 \%$ for fish subjected to collective confinement and most of the deaths occurred in the first hour after capture. These findings suggest that the first hours after release are crucial to the survival of peacock bass caught in catchand-release fishing. In general, post-release mortality has been associated with damage to vital tissues or organs, which leads to profuse loss of blood. This trend was also reported for other species targeted in sport fishing (Muoneke (1992); Muoneke and Childress (1994); Schill (1996); Butcher et al. (2006)), in which the highest fish mortality occurred in the first 24 hours after release.

For fishes returned to the water after capture that have been out of the water for a long time, predation is the major cause of mortality and is the result of physiological and behavioral deficiencies (Cooke and Philipp, 2004). Therefore, telemetry, or any technique that allows fish to be studied in their natural environment, should be used in studies that seek to quantify catch-and-release fish mortality.

Post-capture stress, which is caused by factors such as physical injuries (Meka, 2004) and other disturbances associated with catch-and-release (Stockwell et al., 2002; Siepker, 2005; Pope et al., 2007), can inhibit feeding in the short term. Feeding varies according to the severity and duration of stress factors, as well as the species, age, size and condition of the fish (Pope et al., 2007). When the experiment with collective confinement was over, we had sacrificed some fish at random and observed that they ate Serrasalmus sp. that entered into the surrounded area (personnel observations). These unpredicted events showed that the stress caused by capture was apparently short-lasting and that the injuries from the hooks did not affect the ability of these fish to feed.

It is important to note that none of the fish caught in our experiments suffered injuries to internal organs (apart from the gills). This is most likely due to the use of artificial baits, which are usually not swallowed deeply. Schill (1996), Schisler and Bergersen (1996), Dubois and Kuklinski (2004) and Reeves and Bruesewitz (2007) observed that the chances of fish swallowing the bait are greatly diminished when artificial baits are used as these are operated actively. Although mortality varies between species, higher mortality rates in general are associated with injury to internal organs and lesions with the presence of bleeding that could be associated with the use of natural bait (Muoneke and Childress, 1994; Bartholomew and Bohnsack, 2005; Broadhurst et al., 2005; Reeves and Bruesewitz, 2007; Alós et al., 2008; Alós, 2009).

\section{Acknowledgements}

The authors would like to thank the Amazon Research Funding Agency (FAPEAM) and the National Council for Scientific and Technological Development (CNPq) for providing financial support for this study, and Vila Nunes community for help with field work.

\section{References}

AAS, Ø., THAILING, C.E. and DITTON, R.B., 2002. Controversy over catch-and-release recreational fishing in Europe. In: T.J. PITCHER and C. HOLLINGWORTH, eds. Recreational fisheries: ecological, economic, and social evaluation. Oxford: Blackwell Science, pp. 95-106. http://dx.doi.org/10.1002/9780470995402.ch7.

ALÓS, J., 2009. Mortality impact of recreational angling techniques and hook types on Trachynotus ovatus (Linnaeus, 1758) following catch-and-release. Fisheries Research, vol. 95, no. 2-3, pp. 365369. http://dx.doi.org/10.1016/j.fishres.2008.08.007.

ALÓS, J., PALMER, M., GRAU, A.M. and DEUDERO, S., 2008. Effects of hook size and barbless hooks on hooking injury, catch per unit effort, and fish size in a mixed-species recreational fishery in the western Mediterranean Sea. ICES Journal of Marine Science, vol. 65, no. 6, pp. 899-905. http://dx.doi.org/10.1093/ icesjms/fsn067.

BARTHOLOMEW, A. and BOHNSACK, J.A., 2005. A review of catch-and-release angling mortality with implications for notake reserves. Reviews in Fish Biology and Fisheries, vol. 15, no. 1-2, pp. 129-154. http://dx.doi.org/10.1007/s11160-005-2175-1.

BROADHURST, M.K., GRAY, C.A., REID, D.D., WOODEN, M.E.L., YOUNG, D.J., HADDY, J.A. and DAMIANO, C., 2005. Mortality of key fish species released by recreational anglers in an Australian estuary. Journal of Experimental Marine Biology and Ecology, vol. 321, no. 2, pp. 171-179. http://dx.doi.org/10.1016/j. jembe.2005.02.001.

BUTCHER, P.A., BROADHURST, M.K. and BRAND, C.P., 2006. Mortality of sand whiting (Sillago ciliata) released by recreational anglers in an Australian estuary. ICES Journal of Marine Science: Journal du Conseil, vol. 63, no. 3, pp. 567-571. http://dx.doi.org/10.1016/j.icesjms.2005.10.001.

CATELLA, A.C., 2004 [viewed 10 April 2011]. Reflexões sobre a pesca esportiva no Pantanal Sul: crise e perspectivas [online]. Available from: http://www.agronline.com.br/artigos/artigo. php?id=147.

CECCARELLI, O.S., CANTELMO, O.A. and MELO, J.S.C., 2005. Sobrevivência de peixes capturados na modalidade pesque-solte em viveiros de pesca. Boletim Técnico do Centro Nacional de Pesquisa e Conservação de Peixes Continentais, vol. 18, pp. 19-25.

CECCARELli, O.S., CANTELMO, O.A., MELO, J.S.C. and BOCK, C.L., 2006. Pesque-solte: informações gerais e procedimentos práticos. Brasília: IBAMA. $52 \mathrm{p}$.

COOKE, S.J. and PHILIPP, D.P., 2004. Behavior and mortality of caught-and-released bonefish (Albula spp.) in Bahamian waters with implications for a sustainable recreational fishery. Biological Conservation, vol. 118, no. 5, pp. 599-607. http:// dx.doi.org/10.1016/j.biocon.2003.10.009.

COOKE, S.J. and SUSKI, C.D., 2004. Are circle hooks an effective tool for conserving marine and freshwater recreational catch-and-release fisheries? Aquatic Conservation, vol. 14, no. 3, pp. 299-326. http://dx.doi.org/10.1002/aqc.614

COWX, I.G., 2002. Recreational fishing. In: P.J.B. HART and J.D. REYNOLDS, eds. Handbook of fish biology and fisheries. Cambridge: Blackwell Science, vol. 2, pp. 367-390. http://dx.doi. org/10.1002/9780470693919.ch17. 
DUBOIS, R.B. and KUKLINSKI, K.E., 2004. Effect of hook type on mortality, trauma, and capture efficiency of wild, stream-resident trout caught by active baitfishing. North American Journal of Fisheries Management, vol. 24, no. 2, pp. 617-623. http://dx.doi. org/10.1577/M02-172.1.

FABRI, J.B., 2006. Pesca. In: L. COSTA, ed. Atlas do esporte no brasil. Rio de Janeiro: CONFEF, pp. 9-12.

FREIRE, K.M.F., MACHADO, M.L. and CREPALDI, D., 2012. Overview of inland recreational fisheries in Brazil. Fisheries, vol. 37, no. 11, pp. 484-494. http://dx.doi.org/10.1080/036324 15.2012.731867.

FREITAS, C.E.C. and RIVAS, A.A.F., 2006. A pesca e os recursos pesqueiros na Amazônia Ocidental. Ciencia e Cultura, vol. 58, no. 3, pp. 30-32.

HOLLAND, K.N., WETHERBEE, B.M., LOWE, C.G. and MEYER, C.G., 1999. Movements of tiger sharks (Galeocerdo cuvier) in coastal Hawaiian waters. Marine Biology, vol. 134, no. 4, pp. 665-673. http://dx.doi.org/10.1007/s002270050582.

HOLLEY, M.H., MACEINA, M.J., THOMÉ-SOUZA, M. and FORSBERG, B.R., 2008. Analysis of the trophy sport fishery for the speckled peacock bass in the rio Negro river, Brazil. Fisheries Management and Ecology, vol. 15, no. 2, pp. 93-98. http://dx.doi. org/10.1111/j.1365-2400.2007.00587.x.

KULLANDER, S.O. and FERREIRA, E.J.G., 2006. A review of the South Americancichlid genus Cichla, with descriptions of nine new species (Teleostei: Cichlidae). Ichthyological Exploration of Freshwaters, vol. 17, pp. 289-398.

MCLEAY, L.J., JONES, G.K. and WARD, T.M., 2002. National strategy for the survival of released line-caught fish: a review of research and fishery information. Henley Beach: South Australian Research and Development Institute. $122 \mathrm{p}$.

MEKA, J.M., 2004. The influence of hook type, angler experience, and fish size on injury rates and the duration of capture in an Alaskan catch-and-release rainbow trout fishery. North American Journal of Fisheries Management, vol. 24, no. 4, pp. 1299-1311. http://dx.doi.org/10.1577/M03-108.1.

MUONEKE, M.I. and CHILDRESS, W.M., 1994. Hooking mortality: a review for recreational fisheries. Reviews in Fisheries Science, vol. 2, no. 2, pp. 123-156. http://dx.doi. org/10.1080/10641269409388555.

MUONEKE, M.I., 1992. Hooking mortality of White Crappie, Pomoxis annularis Rafinesque, and Spotted Bass, Micropterus punctulatus (Rafinesque), in Texas reservoirs. Aquaculture Research, vol. 23, no. 1, pp. 87-93. http://dx.doi.org/10.1111/j.1365-2109.1992. tb00598.x.

PITCHER, T.J. and HOLLINGWORTH, C., 2002. Recreational fisheries: ecological, economic, and social evaluation. Oxford: Blackwell Science. 288 p.

POLLOCK, K.H. and PINE, W.E., 2007. The design and analysis of field studies to estimate catch-and-release mortality Fisheries Management end. Ecology, vol. 14, pp. 123-130. http://dx.doi. org/10.1111/j.1365-2400.2007.00532.x.

POPE, K.L., WILDE, G.R. and KNABE, W., 2007. Effect of catch-and-release angling on growth and survival of rainbow trout, Oncorhynchus mykiss. Fisheries Management and Ecology, vol. 14 , no. 2 , pp. 115-121. http://dx.doi.org/10.1111/j.13652400.2007.00531.x.

PROGRAMANACIONAL DE DESENVOLVIMENTO DA PESCA AMADORA - PNDPA, 2006. Guia de pesca amadora. peixes de água doce. Brasília: PNDPA. $130 \mathrm{p}$.
REEVES, K.A. and BRUESEWITZ, R.E., 2007. Factors influencing the hooking mortality of walleyes caught by recreational anglers on Mille Lacs, Minnesota. North American Journal of Fisheries Management, vol. 27, no. 2, pp. 443-452. http://dx.doi.org/10.1577/ M05-209.1.

REINE, K., 2005. An overview of tagging and tracking technologies for freshwater and marine fishes. Vicksburg: Army Engineer Research and Development Center. DOER Technical Notes Collection, ERDC TN-DOER-E18.

SCHILL, D.J., 1996. Hooking mortality of bait-caught Rainbow Trout in an Idaho trout stream and a hatchery: implications for special-regulation management. North American Journal of Fisheries Management, vol. 16, no. 2, pp. 348-356. http://dx.doi. org/10.1577/1548-8675(1996)016<0348:HMOBCR>2.3.CO;2.

SCHISLER, G.J. and BERGERSEN, E.P., 1996. Post release hooking mortality of Rainbow Trout caught on scented artificial baits. North American Journal of Fisheries Management, vol. 16, no. 3, pp. 570-578. http://dx.doi.org/10.1577/15488675(1996)016<0570:PHMORT>2.3.CO;2.

SIEPKER, M.J., 2005. Effects of Recreational Angling on Reproductive Success and Feeding Rates of Largemouth Bass (Micropterus salmoides) and Smallmouth Bass (M. dolomieu). Champaign: University of Illinois at Urbana, 41 p. Doctoral Dissertation.

SIEPKER, M.J., OSTRAND, K.G., COOKE, S.J., PHILIPP, D.P. and WAHL, D.H., 2007. A review of the effects of catch-andrelease angling on black bass, Micropterus spp.: implications for conservation and management of populations. Fisheries Management and Ecology, vol. 14, no. 2, pp. 91-101. http:// dx.doi.org/10.1111/j.1365-2400.2007.00529.x.

SOBREIRO, T., FREITAS, C.E.C., PRADO, K.L., NASCIMENTO, F.A., VICENTINI, R. and MORAES, A.M., 2010. An evaluation of fishery co-management experience in an Amazonian black-water river (Unini River, Amazon, Brazil). Environment, Development and Sustainability, vol. 12, no. 6, pp. 1013-1024. http://dx.doi. org/10.1007/s10668-010-9238-8.

STATSOFT INC, 2009. Statistica: data analysis software system. Version 9.0. Available from: www.statsoft.com.

STOCKWELL, J.D., DIODATI, P.J. and ARMSTRONG, M.P., 2002. A bioenergetic evaluation of the chronic-stress hypothesis: can catch-and-release fishing constrain striped bass growth? In: J.A. LUCY and A.L. STUDHOLME, eds. Catch and release in marine recreational fisheries. Bethesda: American Fisheries Society. pp.144-147.

THOMÉ-SOUZA, M.J.F., MACEINA, M.J., FORSBERG, B.R., MARSHALL, B.G. and CARVALHO, A.L., 2014. Peacock bass mortality associated with catch-and-release sport fishing in the Negro River, Amazonas State, Brazil. Acta Amazonica, vol. 44, no. 4, pp. 527-532. http://dx.doi.org/10.1590/1809-4392201400193.

THORSTAD, E.B., HAY, C.J., NÆSJE, T.F., CHANDA, B. and ØKLAND, F., 2004. Effects of catch-and-release angling on large cichlids in the subtropical Zambezi River. Fisheries Research, vol. 69, no. 1, pp. 141-144. http://dx.doi.org/10.1016/j. fishres.2004.04.005.

VEIGA, P., GONÇALVES, J.M.S. and ERZINI, K., 2011. Shortterm hooking mortality of three marine fish species (Sparidae) caught by recreational angling in the south Portugal. Fisheries Research, vol. 108, no. 1, pp. 58-64. http://dx.doi.org/10.1016/j. fishres.2010.11.021. 